\title{
The Kingdom Is Restored to David
}

\subsubsection{Samuel 19:1-3}

At the lower level of 19:1 Joab is told that the king is grieving over Absalom. In 19:2 it is stated that the day which should have been a day of victory for all of the troops was instead a day of mourning because of the king's grief. In 19:3 the soldiers secretly make their way into the city as though they had fled from the battle and were ashamed. At the upper level of the narrative the ironist implies that David is more concerned about his personal grief than he is for the kingdom. The opposition in the narrative concerns the contrast of David's grief with the soldier's shame. The soldiers should have marched into the city jubilantly, yet they are forced to move into Jerusalem silently and unsure of their reception. The news that the soldiers bring is good for David as a king, but not good news for David as a father. However, the focus of this narrative has been David's failings as a king, and David's failure to lead his people competently. This focus on David's failure as a king may go some way towards addressing Brueggemann's concern that nobody is reported as comforting David in his time of grief and that this constitutes an implied criticism of the Israelite people. ${ }^{1}$ The implication is that while David is understandably grief-stricken, Absalom died as a result of trying to usurp David's throne and, more generally, the interests of the Israelites as a people outweighs the well-being of either David or Absalom. The Israelites have just been engaged in a civil war, which was not of their making.

David is the object of ironic attack since, yet again, he manifests deficiencies as a king. He is also the unknowing victim of irony as he is confidently unaware of both his shortcoming in this context and the irony it gives rise to. The grade of irony is covert as it not immediately apparent. The mode of verbal irony is impersonal and the sub-category is irony displayed. The irony emerges from the arrangement of the events in which David's grief is contrasted with the shame of the soldiers, who should have returned triumphantly.

1 Brueggemann, First and Second Samuel, 324. 


\subsubsection{Samuel 19:4-8a}

At the lower level of 19:4 David cries out for Absalom in a loud voice. In 19:5 Joab comes to the king's house and speaks to the king. Joab tells David that he (David) had covered the faces of all of the officers in shame despite their successful efforts to save David's life and the lives of his sons, daughters, wives and concubines. In 19:6 Joab states that David has shamed these people out of love of those who hate him and he has earned the hatred of those who love him. Joab mentions that David's actions have made it clear to the commanders and officers that they do not mean anything to David, and that he believes that David would be happy if all of the army were dead so long as Absalom remained alive. In 19:7 Joab tells David to go out and speak kindly to his servants because if he does not do so all of his servants will desert him that night; and if that were to happen it would be the greatest disaster ever to befall David. In 19:8 David takes his seat at the gate. The troops are told that David has taken his seat and they come before the king.

At the upper level of the narrative the ironist implies that Joab has once again saved David; in this case by reminding him of his obligations as king and warning him of the political consequences of him not doing so. Similarly, in the Uriah narrative Joab changes David's command to make a situation workable (2 Sam. 11:16-17), and Joab warns David to join the war in Rabbah (2 Sam. 12:27-28). The implied pejorative criticism of David relies in part on the word choice and the exaggerated language in Joab's speech.

McCarter argues that the words love and hate in 19:6 are political terms. ${ }^{2}$ The relationship between David and his soldiers and the relation between David and Absalom is also political (albeit, not entirely so, given Absalom is his son). Accordingly, Joab is warning David to act in favour of those to whom he owes his primary political allegiance in this situation, namely, his soldiers.

Moreover, Joab's warning to David is emphasised by his use of exaggerated language. Anderson writes, "Joab's scathing rebuke of David contains a number of exaggerations. It is questionable (although, not impossible) whether Absalom would have really exterminated the house of David in its entirety, including his wives, concubines, and daughters." ${ }^{3}$ The warning is also emphasised by his use of the scathing language which follows in 19:6. Furthermore, in 19:7 Joab swears an oath and continues his diatribe.

The substance of what Joab says to David is true. David does have a disposable attitude towards the troops and has an unwarranted regard for Absalom who was trying to kill him and usurp his thrown. Although Joab and the

2 McCarter Jr., II Samuel, 409.

3 Anderson, WBC, Vol. 11. 2 Samuel, 227. 
soldiers who killed Absalom have directly opposed David's command, it must be stressed that Absalom was fixated on destroying David and usurping the throne. Even if it were the case that David genuinely believed that he would have been prepared to die in place of Absalom (18:33), he would still be culpable for failing to discharge his duties as king. Moreover, David is contemptuous of the people who serve and protect him.

As detailed above, the ironist in 19:4-8a implies that Joab has saved David by reminding him of his obligations as king and warning him of the political consequences for him and the kingdom of his not doing so. Ironically, although David is the king and, as such, supposedly wise and politically astute, it is his subordinate whose actions are necessary for him to act as a king should. David is the object of ironic attack. While David understands Joab's warning and, and as a consequence, goes to meet the soldiers, it is doubtful that he grasps the irony of the situation. Therefore, he is probably the unknowing victim of irony. The grade of verbal irony is covert and the mode is impersonal. The subcategory is overstatement, albeit the substance of what Joab says is true.

Of note, it is also ironical that Joab, the current saviour of David, was the person who was behind the ruse which tricked David into bringing Absalom back to Jerusalem (2 Sam. 14:2).

\subsubsection{Samuel 9:11-12}

At the lower level of 9:11 David requests Zadok and Abiathar to send a message to the elders of Judah. The message is a question and is as follows: "Why should you be the last to bring the king back to his house? The talk of Israel has come to the king. You are my kin, you are my bone and my flesh; why then should you be the last to bring back the king?" (19:11-12). At the upper level of the narrative this is not a request for information but an implicit threat. The implication is that Israel will restore David to a position of power as king and that it would not only be embarrassing to Judah if they were not the first to do so, but that there will also be dire consequences for ignoring David's threat. The conflict in the narrative is a direct opposition. Instead of asking "Why should you be the last to bring the king back to his house?" The true message of the rhetorical question is the following command, "You must be the first to bring the king back to his house, or else!" This message is strengthened by an allusion to the covenant that the tribes of Israel made with David in Hebron (2 Sam. 5:1). In 2 Samuel 5:1 the Israelites say that they are of the same bone and flesh as David. In 19:12 David sends a message to the elders of Judah which says that they are of the same bone and flesh as David. Thus, the force of David's threat is strengthened by an allusion to the covenant that Judah made with David when they accepted David as their king in place of Saul whom they rejected. David feigns 
innocence in this rhetorical question. David is also the object of ironic attack as he must threaten the Judahites in order to be accepted as king.

The irony is covert as it is not immediately apprehended. The type of irony is impersonal and the sub-category of impersonal irony is the rhetorical question.

\subsubsection{Samuel 19:13-15}

At the lower level of 19:13 David tells Zadok and Abiathar the message he would like relayed to Amasa. The message is as follows: "Are you not my bone and my flesh? So, may God do to me, and more, if you are not the commander of my army from now on in place of Joab". Amasa convinces the Judahites to allow David to return as king, and he does. At the upper level of the narrative the implication is that David is bribing Amasa with the offer of a plumb role in the army. This is in contrast to the appeal to covenantal loyalty and family bonds. The innocence in the narrative is David's feigned ignorance. David is also the object of ironic attack as the narrator is pejoratively critical of David's inducement to Amasa. The irony is covert and impersonal. The sub-category of impersonal irony is innuendo.

\subsubsection{Samuel 19:16-20}

At the lower level of the narrative Shimei hurries to meet King David and does so in the company of a thousand people from the tribe of Benjamin (19:16-17). Also, Ziba waded across the Jordan river with his sons and servants in order to assist David and his retinue in their crossing (19:17-18). Shimei falls down before David when David is about to cross the Jordan. Shimei pleads with David not to find him guilty for his treatment of David when David was fleeing Israel. In particular, Shimei mentions that he knows he has sinned (19:18b-20). At the upper level of the narrative is the implication that, in a corrupt environment, those who speak out for what is right suffer and those who are opportunistic prosper. This implication arises in the incongruity between Shimei who railed against David's unjust behaviour and Ziba who brought David a bribe and was awarded his master's estate in return. This incongruity in the narrative is emphasized in the contrast between Shimei who acts desperately and Ziba who is relaxed and somewhat smug. The innocence is the feigned ignorance of the ironist.

The irony is covert and impersonal irony. The mode of impersonal irony is irony displayed as the events have been displayed or crafted in such a way so as to emphasize the contrast between Shimei and Ziba. The irony is covert as it is not immediately apparent and needs to be discerned from anomalies in the narration. One such anomaly is the exaggerated account of Ziba's actions. In the latter case McCarter claims, “... Hebrew waysallehu hayyarden, the 
meaning of which can be clarified by reference to Aramaic salleh, "cleave, split; penetrate, pass through." The sense here is either that Ziba's party actually split the Jordan, i.e., damned it up so David could cross dryshod, or, more likely that they waded in and conveyed the royal party across on their shoulders". ${ }^{4}$ This would appear to be an overstated presentation of the lengths that Ziba would go to in order to ingratiate himself to David.

\subsubsection{Samuel 19:21-23}

At the lower level of 19:21 Abishai responds to Shimei's plea with the remark, "Shall not Shimei be put to death for this, because he cursed the Lord's anointed?" In 19:22 David responds to Abishai with a few rhetorical questions, including: asking what he should do with the sons of Zeruiah; by asking if anybody in Israel should be put to death on this day; and by asking if it is not the case that David knows that he is king over Israel? In 19:23 David states, upon an oath, that Shimei will not die.

Two of the rhetorical questions in this passage are similar to rhetorical questions that have previously appeared in the SN. For instance, in 2 Samuel 16:9 Abishai says to David concerning Shimei, "Why should this dead dog curse the lord my king? Let me go over and take off his head". I have previously suggested that Abishai's remark is appropriate given that it is against the law to curse the king. Furthermore, I have argued that the ironist in 2 Samuel 16:9 criticises David because his decisions are politically motivated, and not based on the laws.

The second rhetorical question that has already appeared in the SN in a similar form is David's following remark, "What have I to do with you, you sons of Zeruiah, that you should today become an adversary to me?" (2 Sam. 19:22). In 2 Samuel 16:10 David remarks, "What have I to do with you, you sons of Zeruiah? If he is cursing because the Lord has said to him, 'Curse David, who then shall say, 'Why have you done so'. In respect of 2 Samuel 16:10 it has been argued that this is a placatory remark. It can reasonably be argued that the comment in 19:22 is also placatory given that the only reason David is opposed to Abishai's suggestion is that it would anger the Benjamites accompanying Shimei and, thereby, impede his efforts to unify Israel—not because David deplores violence as has been otherwise suggested.

At the upper level, it can be assumed that David's actions have not been adjudicated according to the laws or because of mercy extended towards Shimei. Instead, it would seem that David's is trying to present a public image that is conciliatory. This is, of course, only a pretence as ultimately Shimei is killed

4 McCarter, II Samuel, 420. 
by David's son, at David's instigation, because of his treatment of David (1 Kgs. $2: 8-9 ; 2: 44-46)$. It can, therefore, be assumed that David's emphasis on the word "today" (it is expressed three times in the verse 19:22) implies that there will be no deaths on this day, but certainly at a later date! Therefore, ultimately, David does not keep the oath that he makes with Shimei (19:23). The irony is covert, as it is reliant on background information. The irony is also impersonal, and is conveyed by the presence of rhetorical questions. David is the object of ironic attack, as he is not concerned with upholding laws, but is instead motivated by political manoeuvring.

\subsubsection{Samuel 19:24}

At the lower level of 19:24 it is stated that Mephibosheth came down to meet the king and that he had not taken care of himself since the day that David left. At the upper level of the narrative the implicit message is that Mephibosheth was loyal to David. This implication is conveyed in the overstatement of Mephibosheth's ragged appearance that was consistently ragged until the day that David returned in safety. The implication being that Mephibosheth was so saddened by David's departure from Jerusalem that he could not even look after himself. Note, that this is in stark contrast to Ziba's portrayal of Mephibosheth as an active claimant to David's throne (2 Sam. 16:3). Therefore, the mode of impersonal irony is overstatement. David is the object of ironic attack as the implication is that David has given away the estate of an innocent man. To be specific David has given away the estate of Jonathan's kin whom David had sworn to show חסד to (1 Sam. 20:13-15; 2 Sam. 9:1-10).

The mode of irony is covert as it is not immediately apprehended that the narrative is overstated. The verse begins by suggesting that Mephibosheth went to a great effort to meet David, as it states that Mephibosheth, who was crippled, 'came down' to meet David. ${ }^{5}$ This in itself is not an overstatement, as it would have been a great effort for Mephibosheth to have come down and meet with David. Rather, overstated language is evident in the belaboured description of Mephibosheth's failure to look after himself. Instead of making this fact in succinct terms the narrative draws out the extent of Mephibosheth's lack of self-care by listing the things that he had not attended to. For instance,

\section{ולא־עשה רגליו ולא־עשה שפמו ואת־בגדיו לא כבס}

(... he had not cared for his feet or hands, he had not trimmed his moustache or washed his clothes .... $)^{6}$

5 John Woodhouse, 2 Samuel. Your Kingdom Come. (Wheaton, Illinois: Crossway, 2015), 463.

6 Translation from NJB. 
Lack of physical maintenance was a sign of grief in the Ancient Near East (Ps. 23:5; 45:8; 104:15; Job 1:20; Lev. 19:27). Therefore, the extent of Mephibosheth's concern for David is conveyed in the belaboured description of his lack of selfcare. The implication then is that Ziba had lied to David in 2 Samuel 16:1-4 when he said to David that Mephibosheth was disloyal. ${ }^{7}$ In believing Ziba's deception, David is the object of ironic attack, who does not offer the due process of justice, and who is evidently a fool for being deceived yet again.

\subsubsection{Samuel 19:25-3o}

At the lower level of 19:25 David asks Mephibosheth why he did not go to meet David. Mephibosheth responds that he was deceived by Ziba who did not saddle a donkey as requested by Mephibosheth (19:26) and who slandered Mephibosheth to David (19:27a). In 19:27b Mephibosheth says that David is like "the angel of God" and he asks David to do what seems right to him. This is followed by a further appeal to David (19:28). David responds in 19:29 by awarding Mephibosheth and Ziba half of the disputed estate each. In 19:30 Mephibosheth declines David's offer.

At the upper level of the narrative the ironist implies that David is not like "the angel of God". For this phrase is used to indicate that the king is an excellent administrator of justice (see the discussion in 2 Samuel 14:15-17). In this instance David does not administer justice correctly. For, David is told that Ziba deceived Mephibosheth (19:26), yet he splits the estate between the men. The correct course of action would be to decide who was at fault by recourse to wisdom and good judgement. In doing so the innocent person is vindicated and the guilty person is freed from his or her sin by the punishment of the crime. For instance, in Deuteronomy 25:1-2 it states that if there is a dispute between two men, not only will the innocent man be acquitted, but the guilty man will be punished. Yet, who is the guilty party, Mephibosheth or Ziba? Mephibosheth's closing statement in 19:30 indicates that Mephibosheth is only concerned with David's safety, and indeed, is not preoccupied with the estate. Furthermore, we might conclude that Ziba is the untrustworthy one given that he offers an inducement to David in 2 Samuel 16:2. Therefore, it is a more convincing argument that Mephibosheth was being truthful as opposed to Ziba. Regardless, David's ambivalence concerning who owns the estate is troubling and does not indicate that he is like "the angel of God". On the contrary, God hates bribes and false testimony. Furthermore, David is unlike God in that David does not care for justice. David's lack of concern for justice or חסד

7 Hans Wilhelm Hertzberg, I \& II Samuel, 366. 
is the object of ironic attack in this section. He is also an unknowing victim of this irony.

The conflict in the narrative is the opposition between the statement that David is like the angel of God (19:27) and the implied message, that David is not like the angel of God. Or, that David is not a good administrator of justice. Therefore, the mode of irony is impersonal, and the category is praising in order to blame. The sub-category is (a) praise for desirable qualities known to be lacking.

\subsubsection{Samuel 19:31-39}

At the lower level of the narrative Barzillai escorts David to the Jordan. It is stated that Barzillai is an aged and wealthy man who assisted David while he was in Mahanaim (19:31-32). David invites Barzillai to go to Jerusalem with him, and tells him that he will look after Barzillai in Jerusalem (19:33). Barzillai explains that he is too old to go to Jerusalem (19:34-35) and that he would prefer to return to his home town and die there (19:37). Barzillai then offers David his servant Chimham to go with David and to assist him (19:37). David responds that he will take Chimham with him and treat Chimham in the way that Barzillai would have David treat him. David also says that he will continue to look after Barzillai.

At the upper level the ironist implies that there is more to this communication than meets the eye, particularly with reference to the role of Chimham. At the explicit level Barzillai declines David's offer to travel with David to Jerusalem (19:33) and to be rewarded in this way (19:34-36). Instead Barzillai offers David his servant Chimham ostensibly to David to assist David with whatever David needs (19:37). Yet, David responds that he will do with Chimham whatever seems good to Barzillai and that he will look after Barzillai. This would suggest that the conversation was one of political manoeuvring and dissembling rather than a straightforward exchange of ideas. As such, this episode falls into the sub-category of impersonal irony that is innuendo. The conflict in the two levels is an opposition between what is said and what is meant. Barzillai says that he is offering Chimham to David in order that Chimham serve David, yet, the implied message in the narrative is that Barzillai either cannot or does not want to go to Jerusalem and, in any case, as a wealthy man does not need David's rewards. But rather than refuse David's offer of a reward he suggests that Chimham can accompany David, thereby providing David with a further benefit. However, David responds to Barzillai's offer by saying, in effect, that Chimham will receive the reward due to Barzillai on Barzillai's behalf. Barzillai now goes along with this charade. Barzillai's feigned innocence provides the innocence in the exchange. David is the object of ironic 
attack since presumably he must know that far from providing Barzillai (via Chimham) with a reward for Barzallai's past loyalty he is in fact taking the reward of the servant Chimham for himself.

The irony is covert as it is recognised in the anomalous language. Notably, the exaggeration of Barzillai's response to David, in the form of six rhetorical questions, alerts the reader to the irony in the text. This exchange also meets the requirements for Perry and Sternberg's pattern of irony whereby exaggerated language is followed by concise language. The exaggerated language is expressed in the rhetorical questions and in Barzillai's request to stay in his own town until he dies (19:37a). The concise phrase, where the emphasis lays, is 19:37 $\mathrm{b}$ and is as follows:

(But here is your servant Chimham). ${ }^{8}$

והנה עבדך כמהם - - n

\subsubsection{Samuel 19:41-43}

At the lower level of 19:41 the people of Israel ask the king, David, why the Judeans stole the king away and brought the king, his household and his men across the Jordan river into Judah. In 19:42 the Judeans tell the Israelites that the king is closer in kin to them. They also ask the Israelites the following questions: (1) Why are you angry over this matter?; (2) Have the Judeans eaten at the king's expense?; (3) Has the king given the Judeans any gifts? In the lower level of 19:43 the Israelites respond to the Judeans that they have a greater share in David because they have ten tribes. They also ask why the Judeans have despised the Israelites. In addition, they ask the Judeans whether it is true that the Israelites first spoke of bringing David back as king. The narrator states that the Judeans win the war of words.

The questions being asked are in fact rhetorical questions. As such they have implications at the upper level. The rhetorical question at 19:41 should be understood as an accusation rather than merely a request for information. The Israelites accuse the Judeans of stealing David away. The Judeans respond with rhetorical questions that are also accusations rather than requests for information (19:42). The implication in this set of questions is that the Israelites motives are impure, and that they have accepted bribes. In 19:43 the rhetorical question of the Israelites ("Were we not the first to speak of bringing back our king?") is a response to the previous question of the Judeans, namely, the question as to why the Israelites are angry that David went over to the Judeans. There is a further implication in all this that the Judeans' motives were impure

8 Translation NKJ. 
in taking David to Judea as they needed to be implicitly threatened by David before they decided to bring him back (2 Sam. 19:11-12). The innocence in the narrative is the feigned innocence of the narrator. The grade of irony is overt as the intended message is apprehended immediately. The mode of irony is impersonal and the rhetorical question. Both the Judeans and the Israelites are the objects of ironic attack since they are now fighting over the king that they had just previously fought against!

\subsection{Samuel 20:1-26}

\subsubsection{Samuel 20:1}

At the lower level of 20:1 the Benjaminite, Sheba the Son of Bichri, sounds his trumpet and declares that Israel has no portion or shares in the king and that the Israelites should go to their tents. This is untrue, the Israelites have a larger share in the king than the Judeans do, as is evident in their claim in 19:43. The relevant background knowledge at this point is that David has sent a message to the Judeans suggesting that they should be the first to bring him back as king to Jerusalem (19:11-13). Therefore, the implication at the upper level is that David is not prepared to honour the Israelites share in him. The conflict in the narrative is a direct opposition. Bichri says, "We have no portion in David, no share in the son of Jesse!" (20:1); however, the actual message that he is trying to convey is that although Israel does have a share in David, indeed a larger share than Judea, David will not honour it. The innocence in the narrative is the feigned innocence of the ironist. David is the object of ironic attack as he will not honour the Israelites share in him. The grade of the irony is largely overt given that the Israelites had just said that they do have a share in David in the preceding verse. Therefore, the irony is immediately apprehended. The mode of irony is impersonal and an innuendo.

\subsubsection{Samuel 20:9-10}

At the lower level of 20:9 Joab asks Amasa, "Is it well with you, my brother?" The relevant background knowledge at this point is that David appointed Amasa as commander of his army in place of Joab because Joab killed Absalom. Accordingly, at the upper level the implied message is full of menace and can be interpreted as, "I am going to kill you, you traitor!" The conflict in the narrative is a direct opposition. Joab asks Amasa if he is well when Joab intends to convey that he will harm him. Or if שלום is intended to mean peace rather than well-being then the opposition is between peace and murder. Furthermore, in the lower level Joab calls Amasa "my brother" which suggests the bonding of 
family as opposed to Joab's intended message of traitor, which suggests disunity and enmity. The implied message is confirmed by the actions that surround it. Joab approaches Amasa aggressively with his sword on display (20:8) and possibly even held in his hands (20:10). Furthermore, directly after speaking to Amasa Joab grabs his beard which is an offensive action. ${ }^{9}$ Saliently, Joab kills Amasa (20:10) which indicates that this was not a friendly exchange.

The irony is impersonal and an innuendo. The grade of irony is overt as it is immediately apparent that Joab's aggressive actions conflict with the comment at the lower level.

\subsubsection{Summary of Irony in 2 Samuel 19:1-20:26}

In 19:1-3 the mode of irony displayed suggests that David's decision to ignore the troops was a great insult to them. Verses 19:4-8a show David to lack judgement and be in a state of confusion. For David weeps for Absalom who has set out to destroy him, and yet David is angry at his army who have saved his life. This irony comes through in the use of overstated language. In 19:11-12 David sends a message to the elders of Israel by way of a rhetorical question. At the lower level this question is a request for information at the upper level it is a threat. In 19:13-15 the innuendo implies that David gives an inducement to Amasa. 19:16-20 continues this theme. Ziba is rewarded by David with Mephibosheth's estate when Ziba brings stolen goods from Mephibosheth's estate to David during David's exile. Shimei who stood up for justice is, by contrast, presented as pathetic. Irony displayed brings this contrast to the fore. Of course, in 19:21-23 it would seem that David is kind to Shimei. However, this is only at the lower level. At the upper level the implication is that David is merely trying to present a conciliatory public image. After all he does later order Shimei's execution. The irony in this section arises from rhetorical questions. In 19:24 Mephibosheth's loyalty to David is emphasized by way of ironic overstatement-David does not offer Mephibosheth justice. Thereby, it is no surprise that in 19:25-30 Mephibosheth's comment conveying that David is a good administrator of justice is ironic and a case of praising in order to blame. In 19:31-39 there is an innuendo that David is politically motivated and not motivated by justice. In 19:41-43 the Israelites and the Judeans ask rhetorical questions that are implied accusations. 20:1 is an innuendo that David will not honour the share that the Israelites have in him as king. In 20:9-10 there is an innuendo. Joab asks Amasa if he is well when Joab intends to convey that he will harm him.

9 John Mauchline, 1 and 2 Samuel, 297. 